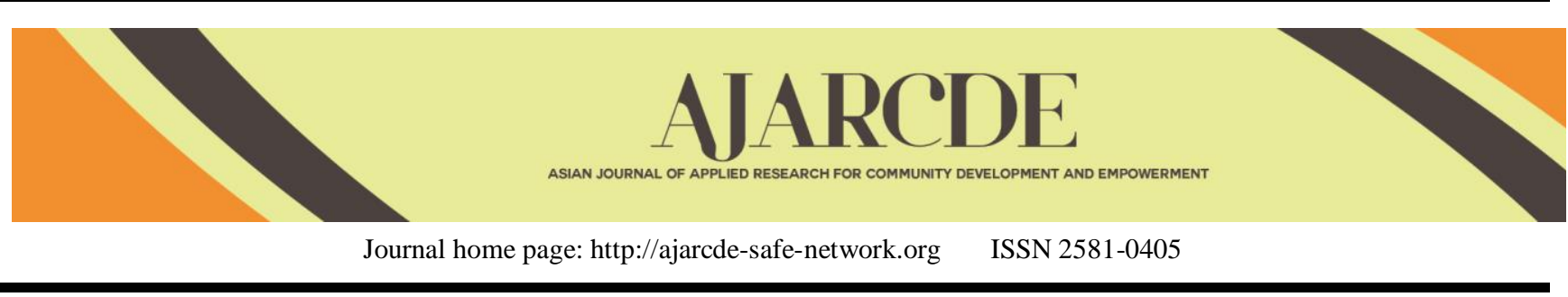

\title{
Flood risk area assessment in Patong Municipality, Kathu District, Phuket Province, Thailand
}

\author{
$S$ Vongtanaboon ${ }^{1}$, W Hancharoen ${ }^{2}$ and $S$ Homya ${ }^{l}$. \\ ${ }^{1}$ Environmental Science Department, Faculty of Science and Technology, Phuket Rajabhat University, Phuket., Thailand, \\ ${ }^{2}$ Entrepreneur Department, Faculty of Social Science, Phuket Rajabhat University, Phuket, Thailand \\ Corresponding author: vongtanaboon@yahoo.com
}

\section{ARTICLE INFO}

Article History:

Received: July 3, 2019

Final Revision: November 14, 2019

Available Online: December 23, 2019

KEYWORDS

Flood, Patong Municipality, land use

\section{CORRESPONDING AUTHOR}

*E-mail: vongtanaboon@yahoo.com

\section{A B $\mathbf{S}$ T $\mathbf{R}$ A $\mathbf{C}$ T}

The objectives of this research were to evaluate risk factors and assess flood risk areas, including analyzing guidelines for flood risk area management in Patong Municipality, Kathu District, Phuket Province. Factors affecting flood were rainfall, slope gradient, soil permeability, land use, and water barrier. Weighting factors and rating factors were indicated and geographic information system for potential surface analysis and overlay analysis were applied. The results revealed that Patong Municipality had high risk area as $2.17 \mathrm{~km} 2(11.39 \%)$. Flood risk area for moderate level accounted for $4.00 \mathrm{~km} 2(20.99 \%)$ and low flood risk area accounted for $12.89 \mathrm{~km} 2$ (67.62\%). Guidelines for flood risk area management in Patong Municipality should focus on the principles of soil and water conservation, forest restoration and preservation in the upstream area, flow path and stream are management, land use management, ground cover planting to prevent soil erosion and maintain soil moisture.

\section{INTRODUCTION}

\subsection{Research Background}

At present, Thailand is experiencing a lot of natural disasters, especially flooding. From the study of flood factors, it was found that important factors that causing flood was the rainfall that fell in the area and neighborhood. There were additional factors that caused the flood problem in the area to become more severe such as slope of the area, distance of the community from the river, soil permeability, landuse and transportation [1-3]. In the analysis of the flood risk area, the geographic information system was applied together with spatial potential analysis by weighting method. Weighting and rating scores were determined by experts from relevant organizations $[4,5]$.

Patong Municipality has a geography with beautiful natural resources. Patong Beach is a place that attracts both Thai and foreign tourists tovisit the city of Patong, thus making it famous and well-known throughout the world and also a place where foreign tourists come to rest all year round. The beach is also equipped with facilities such as hotels, restaurants, water sport equipment stores resulting in the rapid expansion of the city along with the growth of tourism business [6,7] . However at present, Patong municipality often faces flooding problem after several hours of rain, causing the amount of rain to overflow in the canals and streets around Patong, whereas sea inundation results in the inability of water to drain into the sea immediately. Therefore, https://doi.org/10.29165/ajarcde.v3i1.22 there should be a study of flood risk factors in order to indicate the flood risk area in the Patong Municipality. The results of the study will allow people in the area to have knowledge and understanding in preparing for the flood situation.

\subsection{Research Objective}

The objectives of this research were to evaluate risk factors and assess flood risk area, including analyze guidelines for flood risk area management in Patong Municipality, Kathu District, Phuket Province.

\section{MATERIALS AND METHODS}

The method of flood risk area assessment in Patong Municipality, Kathu District, Phuket was as follows:

\subsection{Flood risk factors evaluation}

According to research papers related to flood risk factors, there were affecting 5 factors consisting of rainfall, slope of the area, soil permeability, land use and water barrier.

\subsubsection{Rainfall.}

The maximum daily rainfall in each year during the past 8 years (2001 - 2018) were gathered from the Southern Coast Meteorological Center. The return period was calculated [8] as well as the rainfall intensity and duration. Then the rainfall interpolation was estimated by using statistical processes and 
mathematical equations [9].

\subsubsection{Slope.}

Elevation of the area was surveyed and contour data was interpolated into digital elevation model, then surface slope was analyzed [10].

\subsubsection{Soil permeability.}

Soil data were surveyed and soil permeability were tested and compared with soil characteristics and properties of the Land Development Department.

\subsubsection{Landuse.}

Landuse type and area were surveyed in the study area.

\subsubsection{Waterbarrier.}

Transportation routes were surveyed in the study area.

\subsection{Determination of flood risk weighting factors and rating factors}

Flood risk weighting factors and rating factors were determined based on research papers related to flood [5], [11], [12], [13], [14], [15], [16], [17] including the field survey and observation. (Table $1)$.

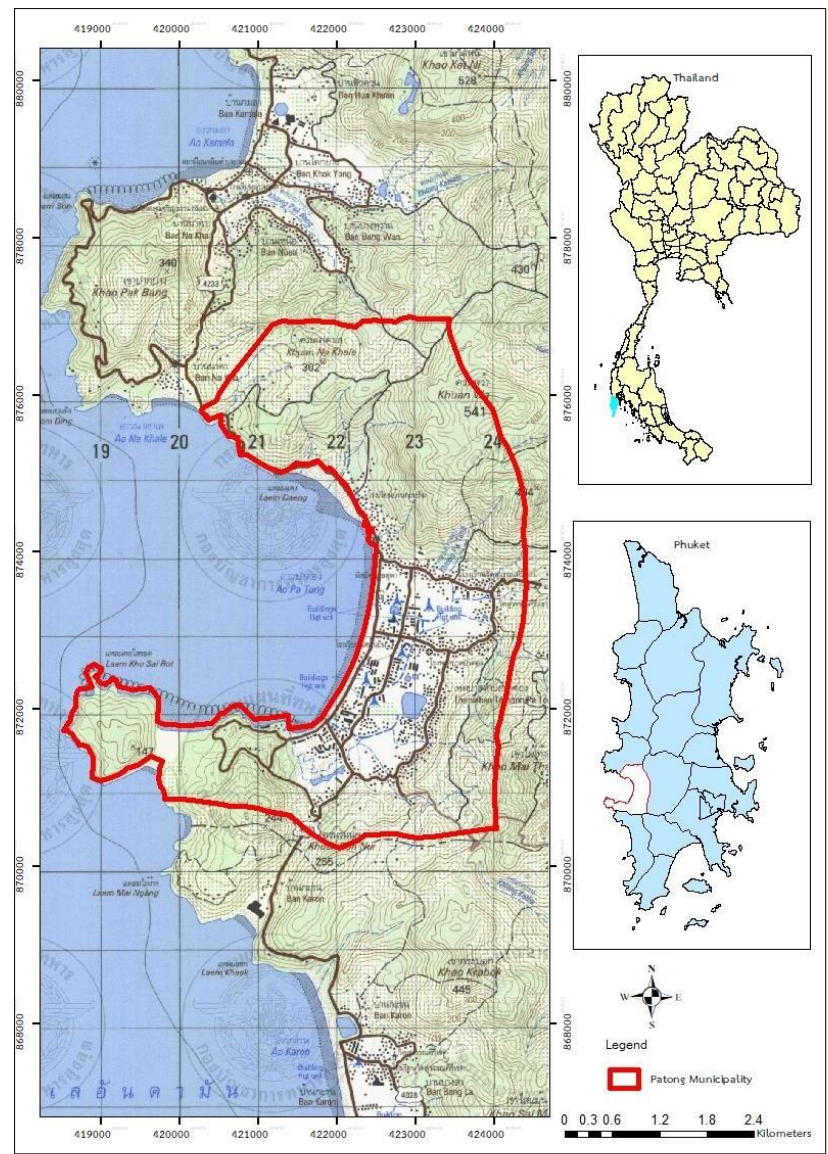

Figure 1. The study area of Patong Municipality, Kathu District, Phuket Province

\subsection{Assessment of flood risk area}

Flood risk factors were overlaid and analyzed to classify the flood risk area with the following equation : $\mathrm{S}=\left(\mathrm{R}_{1} \mathrm{~W}_{1}\right)+$ $\left(\mathrm{R}_{2} \mathrm{~W}_{2}\right)+\left(\mathrm{R}_{3} \mathrm{~W}_{3}\right)+\left(\mathrm{R}_{4} \mathrm{~W}_{4}\right)+\left(\mathrm{R}_{5} \mathrm{~W}_{5}\right)$
The flood risk area analysis was carried out according to statistical methods which was dividedinto 3 levels: high risk level, moderaterisk level and low risk level [13] using the mean value and the standard deviation to determine the width of each range for the risk level.The volume of biogas was monitored and recorded every day; the cumulative gas measured base on the results that noted from daily gas generated. Every 3 days produced gas was collected in the gas sampling bag with $1 \mathrm{~L}$ working volume (Tedlar PVF - PTFE valve, China) and was stored in dry storage and the continuous temperature range from $-70^{\circ} \mathrm{C}$ to $100^{\circ} \mathrm{C}$. The volume of gas used for checking components was $400 \mathrm{ml}-$ $1000 \mathrm{ml}$.

\section{RESULT AND DISCUSSION}

Assessment of flood risk area in Patong Municipality, Kathu District, Phuket Province could be summarized and discussed as follows:

\subsection{Municipality, Kathu District, Phuket Province}

In the study of flood risk factors in Patong Municipality, five flooding factors: rainfall, slope of the area, soil permeability, landuse and water barriers had been compiled to analyze flood riskarea [2], [17].

\subsubsection{Rainfall}

Maximum. Daily rainfall during the year 2001- 2018 in Patong municipality were gathered. It was found that the average daily rainfall in the period of 18 years was $144.1 \mathrm{~mm}$. The maximum rainfall was $211.9 \mathrm{~mm}$ in August 2011 due to the monsoon trough which was quite strongacross theupper Thailand almost throughout the month. By the beginning of the month, the monsoon trough had spread across the northern and northeastern regions, then moved down across the lower northern, central and eastern regions, together with the moderate to strong southwest monsoon covering the Andaman Sea. Such characteristics caused Thailand to heavily rain throughout the month, causing continuous flood in many areas for the southern region. Most of the rainfall was in the middle and late month, especially at the end of the month, the southwest monsoon was strong, causing more rain, resulting in heavy to very heavy rain in many areas of the west side of the southern area [18].

\subsubsection{Slope of the area.}

The slope of Patong Municipality was found that the area with the slope greater than $15 \%$ was 11.60 square kilometers or $60.86 \%$ of the area and it was covered with forest. The area with the slope of $5-15 \%$ was 4.43 square kilometers or $23.24 \%$ which was an agricultural area. The area with the slope less than $5 \%$ was 3.03 square kilometer or $15.90 \%$ which was community and residential area (Table 2).

Whereas $\begin{array}{lll}\mathrm{S} & = & \text { area risk or potential } \\ \mathrm{R}_{\mathrm{i}} & = & \text { rating factors of flood } \\ \mathrm{W}_{\mathrm{i}} & =\quad \text { weighting factors of flood }\end{array}$


Table 2. Slope of the area in Patong Municipality, Kathu District, Phuket Province.

\begin{tabular}{|l|l|c|l|c|}
\hline \multirow{2}{*}{ Slope } & \multirow{2}{*}{ Weighting } & \multirow{2}{*}{ Rating } & \multicolumn{2}{|c|}{ Area } \\
\cline { 4 - 5 } & & $\begin{array}{l}\text { square } \\
\text { kilometer }\end{array}$ & percent (\%) \\
\hline Slope 0 - 5 \% & \multirow{3}{*}{$\begin{array}{l}\text { Slope 5 - 15 } \\
\%\end{array}$} & 3 & 3.03 & 15.90 \\
\hline \multicolumn{2}{|l|}{0.15} & 2 & 4.43 & 23.24 \\
\cline { 4 - 5 } & & & 60.86 \\
\hline \multicolumn{2}{|l|}{ Tlope > 15\% } & 1 & 11.60 & 100 \\
\hline
\end{tabular}

The slope factor was the second factor that affected the flood following the maximum daily rainfall factor. This was consistent with the study of flood factors to determine the risk area with geographic information systems in the Songkhla Lake sub-basin in Phatthalung Province which was found that the additional factors that caused flooding in the study area following the amount of rainfall was the slope of the area [1]. In addition, the application of geographic information systems to determine the flood risk area in Angthong Province was found that geographic characteristics were important factors affecting flood [5].

\subsubsection{Soil permeability.}

Characteristics and properties of soil series in Patong Municipality consisted of Alluvial Complex, poorly drained (AC - pd), Ban Thon series (Bh), Estuaries (EC), Khok Kloi series (Koi), Thai Muang series (Tim) and slope complex (SC). The soil permeability in Patong Municipality was found that the area with high permeability was 12.78 . square kilometers or $67.05 \%$ as slope complex $(\mathrm{Sc})$ area consisting of rock fragments, rocks or rocky surfaces scattered everywhere. Most of them were covered with forests due to the high slope of the area. The area with moderate permeability was 3.89 square kilometer or $20.40 \%$ as Ban Ton series (Bh) and the mixed soil series of Khok Kloi and Thai Muang (Koi \& Tim) with a moderate slope in the granite hillslope area and loamy sand or sandy clay soil. The area with low permeability was 2.39 square kilometer or $12.55 \%$ as Alluvial Complex (AC) and Estuaries (EC) with poor drainage and silty clay soil (Table 3 ).

Table 3. Soil permeability in Patong Municipality, Kathu District, Phuket Province

\begin{tabular}{|c|c|c|c|c|}
\hline \multirow[b]{2}{*}{$\begin{array}{l}\text { Soil water } \\
\text { permeability }\end{array}$} & \multirow[b]{2}{*}{ Weighting } & \multirow{2}{*}{ Rating } & \multicolumn{2}{|l|}{ Area } \\
\hline & & & $\begin{array}{l}\text { square } \\
\text { kilometer }\end{array}$ & \begin{tabular}{|l} 
percent \\
$(\%)$
\end{tabular} \\
\hline $\begin{array}{l}\text { Low } \\
\text { permeability }\end{array}$ & \multirow[t]{3}{*}{0.06} & 3 & 2.39 & 12.55 \\
\hline $\begin{array}{l}\text { Medium } \\
\text { permeability }\end{array}$ & & 2 & 3.89 & 20.40 \\
\hline $\begin{array}{l}\text { High } \\
\text { permeability }\end{array}$ & & 1 & 12.78 & 67.05 \\
\hline \begin{tabular}{|l|} 
Total \\
\end{tabular} & & & 19.06 & 100 \\
\hline
\end{tabular}

In the study, soil permeability factor was the fourth factor affecting flooding in accordance with the application of geographic information systems to assess flood risk area in $\mathrm{Si}$ Racha District, Chonburi province [19], which was found that the fourth factor causing flood was soil permeability.

\subsubsection{Landuse.}

In the study of landuse factor, it was found that the forest area and natural water area was 7.60 square kilometers or $39.87 \%$,

S Vongtanaboon1et al. agricultural area was 3.31 square kilometers or $17.37 \%$, urban area and residential area was 8.15 square kilometers or $42.76 \%$ (Table 4).

Table 4. Landuse type in Patong Municipality, Kathu District, Phuket Province.

\begin{tabular}{|c|c|c|c|c|}
\hline \multirow[b]{2}{*}{ Landuse } & \multirow[b]{2}{*}{ Weighting } & \multirow[b]{2}{*}{ Rating } & \multicolumn{2}{|c|}{ Area } \\
\hline & & & $\begin{array}{l}\text { square } \\
\text { kilometer }\end{array}$ & $\begin{array}{l}\text { percent } \\
(\%)\end{array}$ \\
\hline $\begin{array}{l}\text { Communities and } \\
\text { residences }\end{array}$ & 0.04 & 3 & 8.15 & 42.76 \\
\hline Agricultural area & & 2 & 3.31 & 17.37 \\
\hline $\begin{array}{l}\text { Forests and natural } \\
\text { water sources }\end{array}$ & & 1 & 7.60 & 39.87 \\
\hline Total & & & 19.06 & 100 \\
\hline
\end{tabular}

Lanuse of Patong Municipality that caused the most flooding was communities and residential area, such as Suwannakhiriwong temple, Ban Sai Nam Yen school, Ban Kalim school, Patong hospital, Patong police station, mosque, Patong municipal office and various hotels. When areas were developed to be communities or residences, land was filled and adjusted to build roads and various structures causing water basins, marshes and canals to be completely destroyed. Within the community area that did not establish a proper and effective drainage system, therefore the heavy rainfall could cause flooding for a long time and lead to subsequent damage.

\subsubsection{Water barriers}

The study was found that the area with water barrier less than $0.30 \mathrm{~km} / \mathrm{sq} \mathrm{km}$ was 17.54 square kilometers or $92.03 \%$. The area with water barrier between $0.30-0.60 \mathrm{~km} / \mathrm{sq} \mathrm{km}$ was 0.56 square kilometers or $2.94 \%$. The area with water barrier greater than 0.60 $\mathrm{km} / \mathrm{sq} \mathrm{km}$ was 0.96 square kilometers or $5.03 \%$ (Table 5).

Table 5. Water Barrier in Patong Municipality, Kathu District, Phuket Province.

\begin{tabular}{|l|l|c|l|l|}
\hline $\begin{array}{l}\text { Water barrier } \\
(\mathbf{k m} / \mathbf{s q} \mathbf{~ k m})\end{array}$ & \multirow{2}{*}{ Weighting } & Rating & $\begin{array}{l}\text { Area } \\
\text { Square } \\
\text { kilometer }\end{array}$ & $\begin{array}{l}\text { percent } \\
(\%)\end{array}$ \\
\hline $\begin{array}{l}\text { Water barrier }> \\
0.60\end{array}$ & 0.11 & 3 & 0.96 & 5.03 \\
\hline $\begin{array}{l}\text { Water barrier } \\
0.30-0.60\end{array}$ & & 2 & 0.56 & 2.94 \\
\cline { 4 - 5 } $\begin{array}{l}\text { Water barrier }<0 \\
-0.30\end{array}$ & & 1 & 17.54 & 92.03 \\
\hline Total & & 19.06 & 100 \\
\hline
\end{tabular}

The routes that blocked the canal included Pak Bang canal,

Pak Lak canal, Wang Khi On canal, Bang Ton Khao canal. When comparing with the application of geographic information systems in determining flood risk area in Suphan Buri Province [4], it was found that most areas were covered with more than $0.60 \mathrm{~km} / \mathrm{sq} \mathrm{km}$ of water barrier in Suphan Buri Province.

\subsection{Assessment of flood risk area in Patong Municipality, Kathu District, Phuket province}

For the flood risk assessment in Patong Municipality, the flood risk levelswere divided into 3 levelswhich could be summarized as follows (Table 6 and Figure 2). 


\subsubsection{Low flood risk area.}

The area with low flood risk was 12.89 square kilometers or $67.62 \%$ of the total area in Patong Municipality. Most areas were very steep slopes with high soil permeability. Landuse type was mostly forest. This low risk area was found in Ron Nui hill, Nakalay hill, Wa hill and Khao Maitao Sibsong mountain.

\subsubsection{Moderate flood risk area.}

The area with moderate flood risk was 4.00 squarekilometers or $20.99 \%$ of the total area. Most areas had relatively low slope with moderate soil permeability. Most landuse was agricultural land and community. There were some transportation routes obstructing the water flow and drainage. This moderate risk area was found at Kalim school, Suwannakhiriwong temple, Patong Municipality and Patong Department of Disaster Prevention and Mitigation.

\subsubsection{High flood risk area}

The area with high flood risk was 2.17 square kilometers or $11.39 \%$ of the total area. Most areas were floodplain with very low slope and low soil permeability because of its landuse type as community and residential area. There were transportation routes that hindered the water flow and drainage when heavy rain occurred. This high risk was found at Ban Sai Nam Yen school Patong hospital, Patong police station, Nanai roadand Rat Uthit 200 Years road, which was consistent with the past flooding records in 2017 and 2018.

Table 6. Flood risk levels in Patong Municipality, Kathu District, Phuket Province.

\begin{tabular}{|l|l|l|l|}
\hline \multirow{2}{*}{$\begin{array}{l}\text { Risk level } \\
\text { score }\end{array}$} & Flood risk level & \multicolumn{2}{|l|}{ Area } \\
\cline { 3 - 4 } & & $\begin{array}{l}\text { square } \\
\text { kilometer }\end{array}$ & $\begin{array}{l}\text { percent } \\
(\%)\end{array}$ \\
\hline$>1.90$ & High flood risk & 2.17 & 11.39 \\
\hline $1.54-1.90$ & Medium flood risk & 4.00 & 20.99 \\
\hline$<1.54$ & Low flood risk & 12.89 & 67.62 \\
\hline Total & 19.06 & 100 \\
\hline
\end{tabular}

From the study of [20], it was found that the high flood risk area was usuallydue to heavy rainfall, floodplain area, short distance from stream, landuse of community and residential area and poor soil permeability. According to the previous study [1], it was found that the rainfall amount was the main reason and the most important factor effecting flood followed by topographyand landuse. However, the nature of flooding was mainly caused by overflowing of water from the stream. Based on the assessment and survey of the flood risk area in Patong Municipality, it was able to analyze the guidelines for flood management, prevention and mitigation, including landuse planning which should integrate various measures, including engineering structures and non-structure measures which consisted of soil and water conservation and forest reservation [5].

\section{CONCLUSION}

The pretreatment of solid-state with alkali pretreatment for 3 days and concentrations substrate could effect on the common reed with a significant change of lignocellulose content and metabolism. The substrates of anaerobic digestion with $2 \%$ $\mathrm{NaOH}$-pretreated common reed produced $49 \%$ more biogas when compared to the untreated with $70.1 \%$ methane and yield of cosubstrate $362.26 \mathrm{ml} \mathrm{CH} 4 / \mathrm{g}$ VS. The changes of chemical structures were contributed to the improvement of biodegradability, accessibility of microorganism and the enrichment of biogas production.

\section{REFERENCE}

[1] Akasuwan N, Tepsongkraw P and Nathee W 2009 The study of flood factors to indicate flood risk area by GIS and establish flood prevention and relief in small watershed Songkhla lake, Phatthalung Province J. Humanities, Social Sciences, Thaksin University $3 \mathrm{pp}$ $176-199$

[2] Sermkarndee P, Charoensuk J and Intharaksa T 2014 Analysis of flood risk area using geographic information system, Khuan Khanun District, Phatthalung Province Department of Geo-Informatics, Faculty of Science and Technology, Hat Yai University pp 2160-73

[3] Naka S 2015 Analysis of risk area for flooding in Pa Sak Upper Basin, Lom Sak District, Phetchabun Province Faculty of Agriculture, Natural Resources and Environment, Naresuan University p 96

[4] Phabset S, Sukruean L, and Mangkhla S 2013 Application of geographic information system for determining flood risk area in Suphan Buri Province Faculty of Science, Rajamangala University of Technology Suvarnabhumi, Suphanburi Center p 84

[5] Thanarun S. and Amornsanguansin C 2010 Application of geographic information systems in determining the flood risk area in Ang Thong province. J. Environmental Management 6 pp 19- 34

[6] Eamarun K and Meesakun J 2010 Mr. Wittayakarn Travelers: Phuket Documentary Publishing, Viriya Business Co. Ltd, Bangkok p 104

[7] Patong Municipality 2017 Development strategy plan (2017-2020) Policy and Plan Analysis, Technical and Planning Division, Phuket p 97

[8] Wangwongviroj N 2008 Hydrology. Department of Civil Engineering, King Mongkut's University of Technology Thonburi p 428

[9] Jirakajonkul S 2009 Learning GIS program with the Arc GIS Desktop 9.3.1 S.R. Printing Mass Products Co., Ltd, Nonthaburi p 908

[10] [10]Klindao S 2013 Learning practice Geographic Information System, Arc GIS program. Odeon Store Co., Ltd. Bangkok p 424

[11] Malczewski J 1999 GIS and multicriteria decision analysis. John Wiley and Sons, New York

[12] Yumuang S 20062001 debris flow and debris flood in Nam Ko area, Phetchabun province, central Thailand Environ Geol 51 pp 545-564

[13] Thamikapong S, Kaewkrom P, Punsaeng S and Phusing P 2011 Soil properties and water balance indicators of floods and landslides in critical area Phetchabun Rajabhat University $\mathrm{p} 79$

[14] Chansuri N 2011 Application of geographic information systems for finding flood risk area in Khon Kaen city by analytical hierarchy process. Department of Computer Science, Faculty of Science, Khonkaen University 
[15] Reungmanee S 2015 Flood risk area management in Nopphitam District, Nakhon Sri Thammarat Master's Thesis in Landscape Architecture, Department of Urban Design and Planning, Silpakorn University p 119

[16] Wongtadum T 2016 Flood risk area analysis by analytical hierarchy process in Lower Yom River Basin, Sukhothai Province Undergraduate thesis, Bachelor of Science (Geography), Department of Natural Resources and Environment, Faculty of Agriculture, Natural Resources and Environment, Naresuan University p 83

[17] Roothumnong S 2017 Geo-informatics for flood and drought risk analysis at Khlong Suan Mak Basin, Khampangphet The Golden Teak: Humanity and Social Science J. 23 pp 86 - 103

[18] Meteorological Department 2018 Thailand weather in August Climate center, Meteorological Development, Bangkok

[19] Chatphuti $\mathrm{T}$ and Intharat $\mathrm{T} 2012$ Application of geographic information systems to assess flood risk area in Si Racha District Chonburi province J. Science and Technology Mahasarakrm University 31 pp 408 - 416

[20] Pinyoyang A and Khiangsontia P 2014 Application of geographic information systems to assess flood risk areas in the Lam Takong watershed area Nakhon Ratchasima Takong J. p 51-58. 